\title{
A Review of Critical Success Factors for ERP-Projects
}

\author{
Stephan A. Kronbichler*, Herwig Ostermann and Roland Staudinger
}

University of Health Sciences, Medical Informatics and Technology, Eduard Wallnöfer Zentrum 1, 6060 Hall in Tirol, Austria

\begin{abstract}
ERP projects are complex purposes which influence main internal and external operations of companies. The success of the project directly influences the performance and the survival of the organisation. Recent research has methodically collected plausible data in the field of critical success factors (CSFs) within ERP projects. This article describes how the collected publications were used to identify the main CSFs and how they can be ranked according to the importance of success or failure through a literature review. Because of the influence of CSFs to ERP-projects in general, the term "ERP project" is used in the further parts of this paper. The second part of this paper proposes how CSFs can be integrated into classical ERP project phases. Past researches did nearly not investigate how CSFs which were mentioned in different publications can influence the ERP-project phases. At the end of the paper the trend of CSF in relation of the publication year and the origin of the author are shown.
\end{abstract}

Keywords: Critical success factors (CSF), ERP, ranking, implementation project.

\section{INTRODUCTION}

Business environments are changing and remaining competitive appears to be a challenge for companies. Organisations must improve their business practices and procedures because of the influence of the competitive market on the importance and impact of information systems. Organisations which implemented ERP-systems are benefitting from the assistance of software applications along the supply chain of companies. These ERP-systems support the handling of different business processes like in material management, production, finance, human resource, sales and marketing, the master data and research and development [1-3]. ERP supports a process-oriented view of the company and provides standardised business processes and real-time financial and production information for the management $[3,4]$.

There are not only benefits that can be achieved from a ERP system implementation, there is already evidence of failure in projects related with ERP implementations [5]. Even though the implementation costs were at $\$ 30$ billion in 2004 and have been growing at about 150 percent per year in recent years a lot of companies had problems with the implementation of ERP within the company [6]. According to different studies a lot of ERP projects do not reach the expected results or lead to the failure of the project. A study of [7], for example, listed 117 companies which implemented ERP and had the following results: A quarter of all the projects is out of budget, 20 percent of the projects were abruptly discontinued for various reasons. 40 percent from the remaining 55 percent stated that they did not reach the defined goals within 1 year after the official project end. Although some of these problems arise from technical

*Address correspondence to this author at the University of Health Sciences, Medical Informatics and Technology, Eduard Wallnöfer Zentrum 1, 6060 Hall in Tirol, Austria; Tel: +43 (0)664 8159748;

E-mail: stephan.kronbichler@umit.at aspects, the majority of these problems result from management, social and organisational issues. To implement ERP successfully, these issues must be considered because there are a lot of challenges for organisations during ERP projects. Businesses are expected to change their business processes to fit the standardised business processes from the ERPsolution selected and as a result of that to fully benefit from the ERP [8]. Often project management has a technical focus and nontechnical issues are neglected. The project management only monitors if the project is in time and in budget.

This ongoing research paper clarifies the concepts around the CSF which are affecting the ERP projects. In the ERP literature, a success factor is a factor whose presence increases the probability of a successful implementation [9]. In the second section an extended literature review is presented which shows CSF which were identified by researchers. In the third section the identified CSFs are classified into ERPproject phases. In the section where the results of the review are shown the CSFs are ranked according to their presence in publications. Afterwards different analyses are made and at the end a conclusion shows the limitations and the future research possibilities in this field.

\section{Research Approach}

The purpose of this research is to identify CSFs and to show which CSFs turned out to be of importance in order to provide indispensable information for further ERP-research.

The main steps for the research study are:

- $\quad$ Literature review related with CSF in ERP projects

- Define project phases in ERP-projects

- $\quad$ Allocate the CSF to the project phases

- A ranking of CSF according to their occurrence in the considered literature

- Show the trend of the CSFs over the years and culture dependent 
Table 1. CSF / Umbrella Term

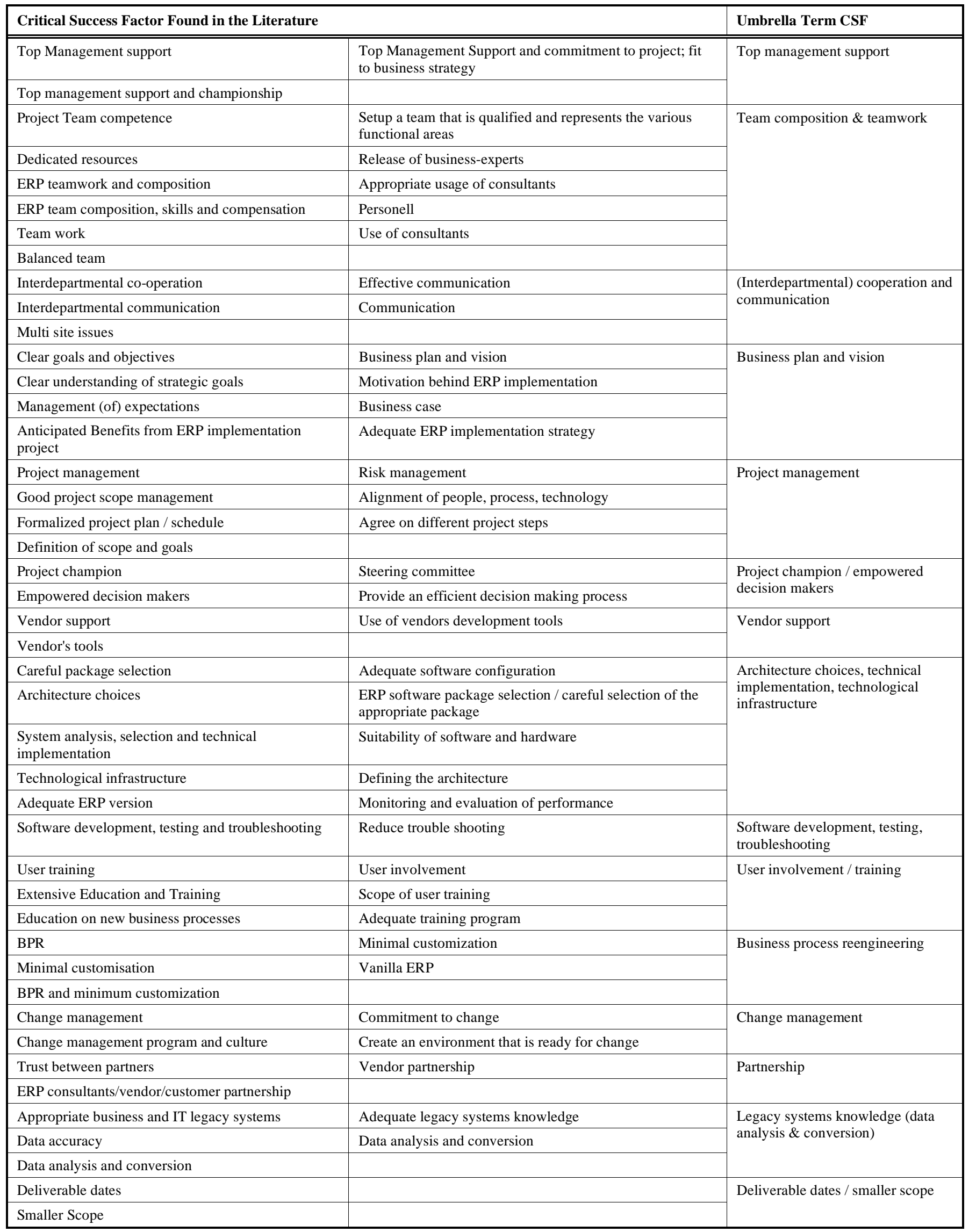


Through an extensive review of the existing literature 23 publications were identified which were considered in the Table 3 in this paper. After finishing the literature review and the aggregation, project phases were first identified through a literature review and then an adequate process model was selected. In a third step the CSF were integrated into three project phases which are typically for ERP projects: the pre-implementation, implementation and the postimplementation phase. At the end of the paper as a result there is a table with different rankings which shows the importance of CSFs from different points of view.

\section{CRITICAL FACTORS FOR ERP-PROJECT SUCCESS}

\section{Methodology of Collection}

The search term for appreciable publications was "critical" and "ERP". Every result was analysed through a review of the abstract. The findings of the first step of the literature review were analysed and further publications in the subject of CSF were found. The CSFs identified in the literature were collected in a spreadsheet and afterwards aggregated to similar groups because authors mentioned the same CSFs with different notations. The list of identified CSFs and the defined umbrella terms are shown in Table 1. To build umbrella terms it was necessary to analyse what authors mean with the CSF they identified in their research paper because of the different names. There were 78 different CSF mentioned and afterwards they were aggregated to $15 \mathrm{CSFs}$ which are shown in Table $\mathbf{1}$ and used for the further analyses of this research. In the next section the CSF which were aggregated are mentioned and the authors who identified them. The limitation of this methodology is that the number of CSFs are depending on the detail which is used by the researcher. The possibility to build umbrella terms is not limited to 15 , it could be 10 or 25 too. In this paper the authors tried to detail the CSFs as much as necessary to find a umbrella term for every CSF found in the review.

\section{Explanation of CSF}

In the following section the umbrella terms of Table $\mathbf{1}$ are explained. To provide a better overview of the CSF which are influencing the umbrella term the CSFs which were distillated are cursive.

\section{Top Management Support}

The authors of [10] define top management concerns in the ERP context with 4 dimensions which must be supported by top management:

\section{- Change Management Dimension \\ - Process Dimension \\ - People Dimension \\ - $\quad$ Project Dimension}

Top Management has to support the whole implementation process and the project needs to be authorised by top management [10-14]. The authors of [11] mention additionally that top management needs to constantly monitor the progress of the project. In 2002 chief financial officers and information officers selected the statement "Executive management should endorse the ERP project" as most important [15]. According to the remarks above the CSFs Top Man- agement Support, Management support and championship, commitment to project and fit to business strategy were aggregated to the CSF Top Management Support.

\section{Team Composition \& Teamwork}

According to the existing literature Team composition and Teamwork is very important for successful ERPimplementation. An ERP project involves all of the functional departments in an enterprise. It needs the cooperation of technical, business experts and external consultants as well as the involvement of end-users in different project phases $[6,16,17]$. According to [2] the ERP project team comprises of functional personnel and management, IT personnel and management, top management, ERP vendor, parent company employees, management consultants and the hardware member. The success of ERP projects is releated to the knowledge, the skills, the abilities and the experiences of the project team members but externals should be used as true consultants and not as long-term additions to internal staff [18]. External knowledge is often needed to facilitate successful implementation with the new technology [12].

Team composition \& teamwork includes the CSFs Project Team competence, dedicated resources, use of consultants, ERP teamwork and composition, "ERP team composition, skills and compensation", team work, personnel, appropriate usage of consultants, balanced team, release of business-experts and "setup a team that is qualified and represents the various functional areas".

\section{(Interdepartmental-) Cooperation and Communication}

Communication and cooperation should be of two kinds: inwards the project team and outwards to the whole organisation [16, 19-21]. It is necessary to create an understanding and an approval of the implementation. Sharing information between the project team and communicating the results and the defined goals to the rest of the organisation in each project stage is as important too [2]. This CSF consists of communication, interdepartmental co-operation, interdepartmental communication and effective communication.

\section{Business Plan and Vision}

A clear business plan and vision should be behind the implementation strategy to know in which direction the project must be steered [21-24]. In project management three often competing and interrelated goals that need to be met are mentioned: scope, time, and cost goals [2]. There must be a clear business plan how the goals can be achieved.

Business plan and vision summarises the CSFs clear goals and objectives, management (of) expectations, anticipated benefits from ERP implementation project, business plan and vision, adequate ERP implementation strategy, motivation behind ERP implementation, multi site issues and business case.

\section{Project Management}

Project Management coordinates the use of skills and knowledge. Furthermore it monitors the progress and the achievement of objectives of the according ERP project. The formal project implementation plan defines milestones like 
project activities, personnel planning on activities and organises the ERP project process [2, 25]. The implementation of an ERP system is a complex project which involves a possibility of occurrence of unexpected events. Therefore the management of risk is needed to minimise the impact of unplanned incidents by identifying potential risks before negative consequences occur $[2,26]$.

Project management consists of the following CSF: good project scope management, formalised project plan / schedule, definition of scope and goals, risk management, "alignment of people, process and technology" and agree on different project steps.

\section{Project Champion / Empowered Decision Makers}

The author of [27] made a literature review and defined a project champion as "any individual who made a decisive contribution to the innovation by actively and enthusiastically promoting its progress through critical stages in order to obtain resources and/or active support from top management". According to [28] the project leader is clearly a "champion" for the project and his role is critical to marketing the project within the organisation.

Project champion / empowered decision makers summarises the CSFs project champion, empowered decision makers, steering committee and provide an efficient decision making process.

\section{Vendor Support}

The ERP implementer-vendor partnership is a key success factor influencing ERP implementation success [17, 21, $25,29]$. Every enterprise has its own ideas how to implement and adopt a system. Ideas of the ERP-vendor can contrast with the customers wishes. Synthesising these differences is hard work [30].

This CSF consists of the CSFs vendor support, vendor's tools and the use of vendor's development tools.

\section{Architecture Choices, Technical Implementation, Technological Infrastructure}

The selection of the adapted ERP software is difficult because there various of ERP packages available on the market and every product has its own strengths and weaknesses, both from products site and ease of implementation [24]. It is necessary to continuously measure the performance of the ERP implementation to assess the developments and the problems occurring [14, 31].

This CSF covers the following CSFs mentioned in the literature: Careful package selection, architecture choices, system analysis, selection and technical implementation, technological infrastructure, adequate ERP version, adequate software configuration, ERP software package selection / careful selection of the appropriate package, suitability of software and hardware, defining the architecture and monitoring and evaluation of performance.

\section{Software Development, Testing and Troubleshooting}

According to [32], the system developers and managers should concentrate on developing better systems rather than focusing on user satisfaction. Quality Assurance is essential, it should be established in the early phases of ERP implementation to avoid wrong results and costly correction afterwards [33].

This CSF consists of software development, testing and troubleshooting and reduce trouble shooting.

\section{User Involvement / Training}

The complexity of ERP systems results in enormous learning curves and behavioural changes for users [14]. ERP projects require significant amount of involvement and dedication to the project [24]. If there is no training program this results in low acceptance and curbs the progress of the project $[21,34]$. This means reskilling users in new technologies and training in the use of specific application modules [28]. Key users of a company should not only be experts in the company's processes but also be aware of the knowledge of information systems in the specific branch. Involving users can decrease their resistance to the potential ERP system, if users have feelings that they are the people who choose and make the decision [25].

This CSF summarises the CSFs user training, extensive education and training, education on new business processes, user involvement, scope of user training and adequate training program.

\section{Business Process Reengineering}

Enterprise system vendors have designed "best practices" by consulting with customers and many of these best practices can be used for BPR (Business Process Reengineering). Otherwise customisation and adoption is needed to change the business processes implemented in the ERP software [35, 36]. ERP systems are built on best practices for the specific industry, and to successfully install ERP, all the processes in a company have to conform to the ERP model [14, 37]. This is one of the reasons why many consulting firms deliver standard systems which are called Vanilla ERP [38-40]. [41] found out that the user is more satisfied with more customisation and the thereby arising new capabilities of the system [42]. The project manager is in a dilemma between BPR and customisation of the ERP system. According to [43], IT is influencing the business processes and those processes are directly influencing the performance of companies. The authors of [44] found out that the higher the degree of customisation, the lower will be the performance of ERP projects.

This CSF includes the following CSFs: business process reengineering, minimal customisation, BPR and minimum customisation, minimal customisation and vanilla ERP and business process reengineering which were mentioned in the literature.

\section{Change Management}

For many companies the hardest challenge in implementing ERP is change management [45]. According to [46] there are 3 levels of change management: At the most straightforward level companies act directly, at the next level employees may need to adjust their practices or adopt new ones and at the deepest level it's a cultural change which is necessary. There are different change management strategies which are necessary to change the attitudes of potential users 
and to inform them about the benefits of ERP [47]. The way people do their jobs needs change, change management is essential for preparing a company for the introduction of an ERP [14, 48, 49].

This CSF consists of change management, change management program and culture and commitment to change.

\section{Partnership}

During different phases of ERP projects there are usually three major parties involved. That means the organisation implementing the system, the organisation that developed the ERP system and an organisation aiding the implementation [50]. A good commercial partnership will ease achievement of the goals defined [19]. External perspectives and knowledge can contribute much to the ERP project because suppliers can be utilised as resources brought in, to work under inhouse direction and control [51].

The affecting CSFs are trust between partners and ERP consultants/vendor/ customer partnership.

\section{Legacy Systems Knowledge}

To manage the complexity of legacy systems is an important part of a successful ERP implementation or ERPalternating project [30]. In the early days of an ERP project it is often hard to know how many and which legacy systems will have to be retained [39]. According to [52] and [39] the majority of difficulties experienced during ERP implementations were the costly developments of additional software as an interface to the legacy systems for master data as well as for transaction data.

In the literature there are the three CSFs appropriate business and IT legacy systems, adequate legacy systems knowledge and data analysis and conversion mentioned.

\section{Deliverable Dates / Smaller Scope}

An initial decision for an ERP project is to decide if and how much the ERP software has to be modified. There is a correlation between the amount of change and the complexity and length of the ERP project. The scope of the modification of the ERP system is a key decision at the beginning of the project [53]. That's the reason for the aggregation of the 2 CSFs deliverable dates and smaller scope.

\section{ERP IMPLEMENTATION PROJECT PHASES}

According to [54], synthesised project model there are 4 phases for ERP implementation: planning, implementation, stabilisation and improvement. The authors of [54] identified CSFs while implementing ERP in 2 companies and classified them into the mentioned process model. In the improvement phase there were no CSFs which affected the ERP implementation in a critical way. The authors of [55] mentioned 4 phases, 3 of them are affecting the implementation of an ERP system (and CSF). These phases are the project chartering which is similar to the planning phase, the project phase which means implementation and the shakedown phase which consists of stabilising, eliminating bugs and getting to normal operations. [57] mentioned the following phases which are similar to the other models: "requirement analysis and specification", "conceptual design", "code development and verification" and "testing and installation". The author of [48] classified the ERP implementation process into the five phases design, implementation, stabilisation, continuous improvement and transformation. The following process is the result of a synthesis of the model mentioned by the authors who published $[48,54,55,57]$. The process of Fig. (1) was selected for the assignment of CSF into project phases. The phases mentioned are: pre-implementation, implementation and post-implementation. The stabilisation and the improvement phases are not clearly set aside, that's why the 2 phases are summarised in one phase.

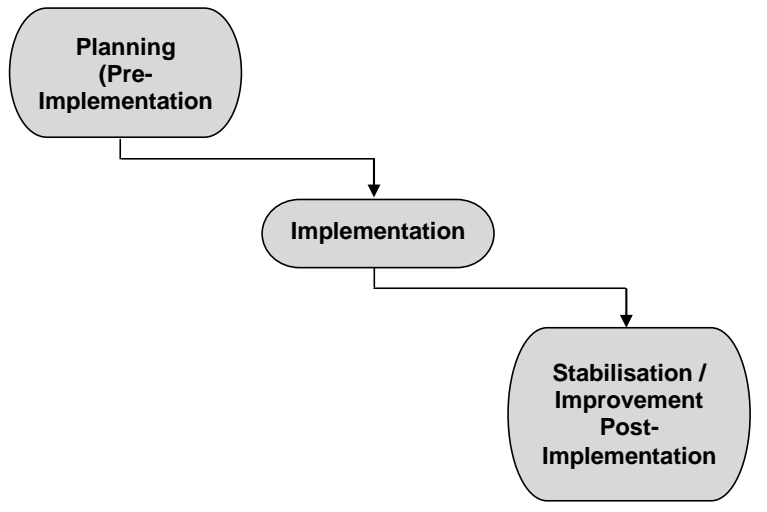

Fig. (1). Modified ERP Project Process [48, 54, 55, 57].

\section{Planning - (Pre)-Implementation}

ERP packages provide a lot of customising possibilities which enhance the configuration of the software. But they make assumptions of the data flow which are often not corresponding to the legacy system data flow. Process change is a key decision during the planning stage of an ERP project [48]. According to [55] this phase is called the chartering phase. Key activities in this phase are building a business case for enterprise systems, selecting a software package, identifying a project manager and approving a budget and a project schedule. According to [54] the planning phase is mostly concerned with selecting the ERP system, scoping the project, formulating the system architecture, development of the business case, identification of a project manager and approval of budget and schedule.

\section{Implementation}

According to [48] even with careful planning and training, going live usually can be highly disruptive. An ERP is a commitment to a new way of doing business and employees need training to do their jobs. The implementation phase, which is called project phase according to [55], comprises activities intended to get the system up and running in one or more organisational units. Every ERP project needs an implementation phase in which the changes of the system or the new functionality used is going live. Key activities are software configuration, system integration, testing, data conversion, training, and rollout. A large number of errors and problems can occur [55].

\section{Stabilisation / Improvement - (Post-) Implementation}

Characteristic activities in the stabilisation / improvement phase include bug fixing and rework, system performance tuning, retraining, staffing up to handle temporary inefficiencies, continuous business improvement, additional user 
skill building and post implementation benefit assessment. This is the phase in which the errors of prior phases are felt in the form of reduced productivity or business disruption. But it is also possible that new errors occur in this phase too [55].

During stabilisation the project team should clean up processes and data and performance of the systems should be improved. After stabilisation continuous improvement is needed. That means that the functionality should be increased and other improvements should be implemented by the project team [48].

\section{CSF / PROJECT PHASE}

Based upon a literature review research papers in the field of CSF in ERP projects were analysed and those publications which identified CSF in project phases were used to make a comparison of project phases and the according CSF.

CSF can be classified by the project phases which are affected by CSFs in a critical way. In the following Table 2 the CSF identified in the previous chapter are classified into the project phases of Fig. (1). To assign CSF to project phases [39, 53, 54] and [29] made a research where they identified CSF within project phases. The authors of [53] used the PPM model which has similar project phases but different characterisation than the model of Fig. (1). The authors additionally identified factors of importance for each phase / CSF. These 4 publications were used as a basis to classify the identified CSF into the project model of Fig. (1).

Table 2 shows the result of the analysis. It shows that the CSF in each project phase are different and some of them are affecting the whole project cycle. The stuffing of the project team seems to be very important for the ERP project because team composition \& teamwork was identified in every single phase. Another CSF which seems to be important from that point of view is "deliverable dates / smaller scope" which is affecting all phases too. If the timelines are too tight and the project scope is too large it seems nearly impossible to reach the expected result. "Project champion / empowered decision makers" was mentioned in every stage of the project too, because such a role is needed in every phase when backstrokes occur and criticism is coming up. Software development, testing and troubleshooting for example is only affecting the implementation phase, but in this phase it is one of the key CSF.

The number at the right of the CSF shows which author identified the CSF in the according project phase.

Table 2. CSF in ERP Project Phases

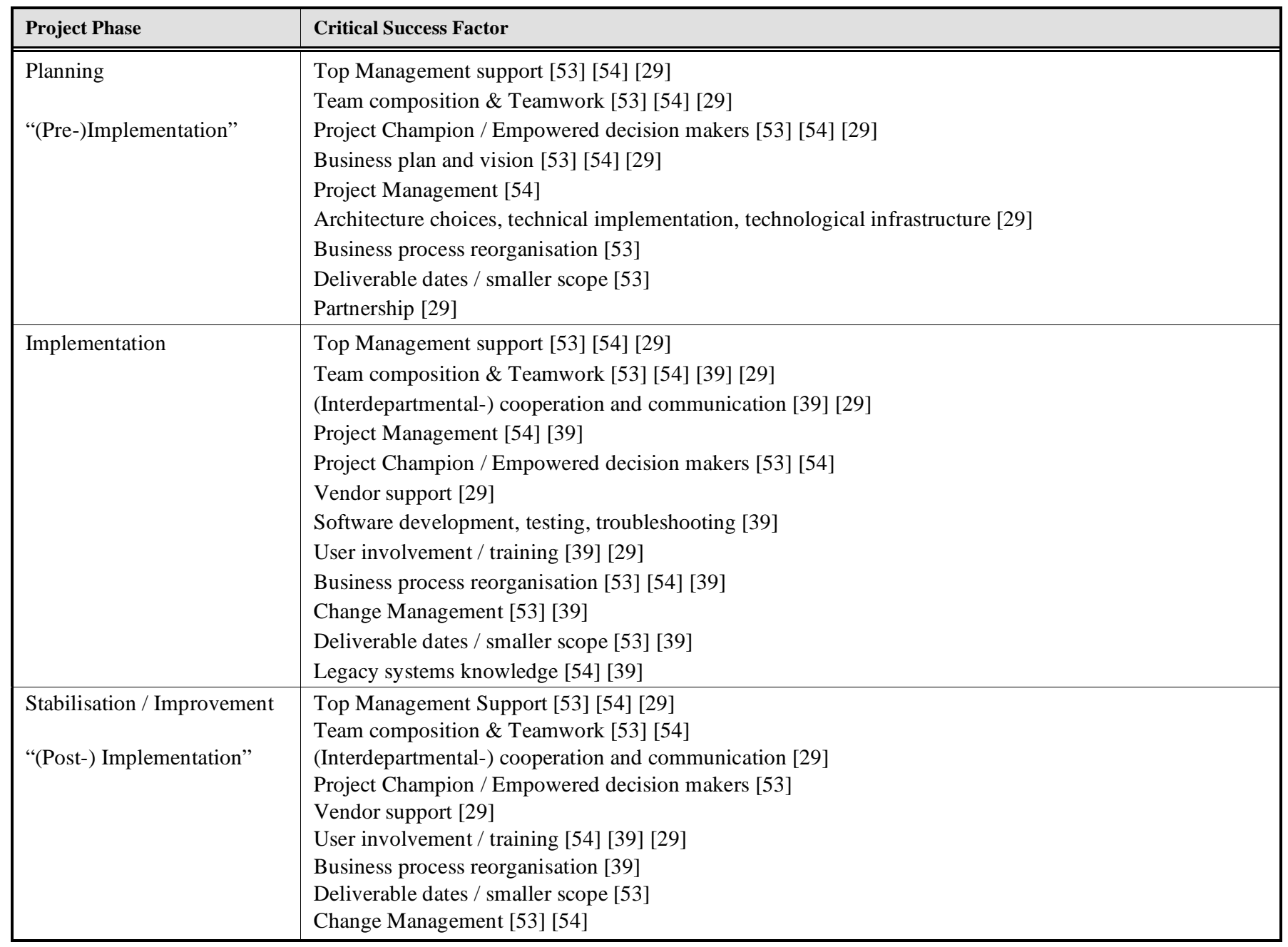




\section{RESULTS OF LITERATURE REVIEW}

As a result of the extensive research in the field of CSFs through a review of the literature, a ranking of CSFs according to their occurrence in the exisiting publications was created. The CSFs which were identified through the review of the publications in the field of CSFs in ERP projects were classified into the CSFs of Table 3.

A lot of researchers made investigations were they identified CSFs in ERP projects on the basis of practical experiences within companies. These publications were analysed and admitted to Table 3 if the author of the publication identified at least 3 CSFs. If the author identified, e.g., only one success factor, the list of the identified CSFs is not intended to be exhaustive and the statistics may be adulterated.

Not only the number of occurrence of each CSF but also the importance in different project phases was considered when compiling Table 3. It consists of the CSFs mentioned in the first part of this paper and the CSF / project phase compilation of Table 2. To find out which CSF has critical impact on a project phase was possible through the review of the CSF literature which identified CSF in ERP project phases. The classification into different phases should make it easier for ERP project managers or risk managers to identify potential risks for the ERP project.

Table 3. Aggregation and Ranking of CSF

\begin{tabular}{|c|c|c|c|c|c|c|c|c|c|c|c|c|c|c|c|c|c|c|c|c|c|c|c|c|c|c|c|c|}
\hline $\begin{array}{l}\text { Author } \\
\text { CSF }\end{array}$ & {$[2]$} & [4] & [11] & [13] & [14] & [20] & [22] & [23] & {$[25]$} & [28] & [29] & {$[30]$} & [31] & {$[33]$} & {$[53]$} & [54] & {$[56]$} & [57] & [59] & {$[60]$} & {$[61]$} & {$[62]$} & {$[63]$} & $\Sigma$ & $\mathbf{A}$ & B & C & D \\
\hline $\begin{array}{l}\text { Top management } \\
\text { support }\end{array}$ & $x$ & $X$ & $X$ & $X$ & $X$ & $X$ & $\mathrm{X}$ & $X$ & $\mathrm{X}$ & $X$ & $X$ & $X$ & $X$ & $X$ & $X$ & $X$ & $X$ & & $X$ & $\mathrm{X}$ & & $X$ & $X$ & 21 & 12,00 & 1 & 3 & 91,30 \\
\hline $\begin{array}{l}\text { Team composition } \\
\& \text { teamwork }\end{array}$ & $X$ & $X$ & $X$ & & & $X$ & $\mathrm{X}$ & $X$ & & $X$ & $X$ & $X$ & $X$ & $\mathrm{X}$ & $X$ & $X$ & $X$ & $X$ & $X$ & & $X$ & & $X$ & 18 & 10,29 & 4 & 3 & 78,26 \\
\hline $\begin{array}{l}\text { (Interdepartmental) } \\
\text { cooperation and } \\
\text { communication }\end{array}$ & & $X$ & & & & $X$ & $\mathrm{X}$ & & & $X$ & $X$ & $X$ & & $\mathrm{X}$ & & $X$ & $X$ & $X$ & & $\mathrm{X}$ & $X$ & & $X$ & 13 & 7,43 & 7 & 3 & 56,52 \\
\hline $\begin{array}{l}\text { Business plan and } \\
\text { vision }\end{array}$ & $X$ & $X$ & & $X$ & & $X$ & $\mathrm{X}$ & $X$ & & & $X$ & $X$ & $X$ & $\mathrm{X}$ & $X$ & $\mathrm{X}$ & $X$ & $X$ & & $\mathrm{X}$ & $X$ & & $X$ & 17 & 9,71 & 5 & 1 & 73,91 \\
\hline $\begin{array}{l}\text { Project } \\
\text { management }\end{array}$ & $X$ & $X$ & & $\mathrm{X}$ & & $X$ & $\mathrm{X}$ & & $X$ & $X$ & $\mathrm{X}$ & $X$ & $X$ & $\mathrm{X}$ & $X$ & $\mathrm{X}$ & $\mathrm{X}$ & $X$ & & $\mathrm{X}$ & $X$ & $X$ & $X$ & 19 & 10,86 & 3 & 1 & 82,61 \\
\hline $\begin{array}{l}\text { Project champion / } \\
\text { empowered } \\
\text { decision makers }\end{array}$ & & & & & & $\mathrm{X}$ & & & & $\mathrm{X}$ & $\mathrm{X}$ & $\mathrm{X}$ & & & & $\mathrm{X}$ & $\mathrm{X}$ & $\mathrm{X}$ & & & $X$ & $\mathrm{X}$ & & 9 & 5,14 & 8 & 3 & 39,13 \\
\hline Vendor support & & & & & & & & & & & $\mathrm{X}$ & & & & & & & & & & & & & 1 & 0,57 & 11 & 2 & 4,35 \\
\hline $\begin{array}{l}\text { Architecture } \\
\text { choices, technical } \\
\text { implementation, } \\
\text { technological } \\
\text { infrastructure }\end{array}$ & $\mathrm{X}$ & $X$ & & & $X$ & $\mathrm{X}$ & $\mathrm{X}$ & & $X$ & $X$ & $X$ & & $\mathrm{X}$ & & & & $\mathrm{X}$ & $X$ & & $\mathrm{X}$ & $X$ & $\mathrm{X}$ & & 14 & 8,00 & 6 & 1 & 60,87 \\
\hline $\begin{array}{l}\text { Software } \\
\text { development, } \\
\text { testing, } \\
\text { troubleshooting }\end{array}$ & & & $\mathrm{X}$ & & & $\mathrm{X}$ & $\mathrm{X}$ & & & & & & & $\mathrm{X}$ & & & & & & & $\mathrm{X}$ & $\mathrm{X}$ & & 6 & 3,43 & 9 & 1 & 26,09 \\
\hline $\begin{array}{l}\text { User involvement / } \\
\text { training }\end{array}$ & $x$ & & & $X$ & & $\mathrm{X}$ & & & $X$ & & $\mathrm{X}$ & $X$ & $\mathrm{X}$ & & & & & & & $\mathrm{X}$ & & & $\mathrm{X}$ & 9 & 5,14 & 8 & 2 & 39,13 \\
\hline $\begin{array}{l}\text { Business process } \\
\text { reengineering }\end{array}$ & $x$ & & $\mathrm{X}$ & & $\mathrm{X}$ & $\mathrm{X}$ & $\mathrm{X}$ & & $\mathrm{X}$ & $X$ & $\mathrm{X}$ & $X$ & & $\mathrm{X}$ & $X$ & $\mathrm{X}$ & $\mathrm{X}$ & & $X$ & $\mathrm{X}$ & $X$ & $\mathrm{X}$ & $\mathrm{X}$ & 18 & 10,29 & 4 & 3 & 78,26 \\
\hline $\begin{array}{l}\text { Change } \\
\text { management }\end{array}$ & $\mathrm{X}$ & $\mathrm{X}$ & $\mathrm{X}$ & & $\mathrm{X}$ & $\mathrm{X}$ & $\mathrm{X}$ & & & $\mathrm{X}$ & $\mathrm{X}$ & $\mathrm{X}$ & $\mathrm{X}$ & $\mathrm{X}$ & $\mathrm{X}$ & $\mathrm{X}$ & $\mathrm{X}$ & $\mathrm{X}$ & $\mathrm{X}$ & $\mathrm{X}$ & $\mathrm{X}$ & $\mathrm{X}$ & $\mathrm{X}$ & 20 & 11,43 & 2 & 2 & 86,96 \\
\hline Partnership & & & & & & $\mathrm{X}$ & & & & & $\mathrm{X}$ & & & & & & & & & & & & & 2 & 1,14 & 10 & 1 & 8,70 \\
\hline $\begin{array}{l}\text { Legacy systems } \\
\text { knowledge (data } \\
\text { analysis \& } \\
\text { conversion) }\end{array}$ & & & & & & $\mathrm{X}$ & $\mathrm{X}$ & & $\mathrm{X}$ & & $\mathrm{X}$ & & $\mathrm{X}$ & & & & $\mathrm{X}$ & & & & & & & 6 & 3,43 & 9 & 1 & 26,09 \\
\hline $\begin{array}{l}\text { Deliverable dates / } \\
\text { smaller scope }\end{array}$ & & & & & & & & & & & & & & & $X$ & & & & $\mathrm{X}$ & & & & & 2 & 1,14 & 10 & 3 & 8,70 \\
\hline$\Sigma$ & 8 & 7 & 5 & 4 & 4 & 13 & 10 & 3 & 6 & 8 & 13 & 9 & 8 & 8 & 7 & 8 & 10 & 7 & 5 & 8 & 9 & 7 & 8 & 175 & 100 & & & \\
\hline
\end{tabular}

Number of the author [ ] according to the references at the end ¿Sum of the column / line.

A relation to the totality in \% (rounded).

B Ranking according to A.

C Number of appearance in ERP-implementation process.

D percentage of the publications which identified the CSF. 
Table 3 should help ERP projects in the future to use the experiences made in this research to achieve more success in their projects. It can be used for different forms of ERP projects, for the adoption, the deployment and the use of ERP systems. The outcome should be that companies can easily recognise what other companies do and what key success factors are influencing ERP projects. Some companies achieve better or worse outcomes than others. Knowing what factors are influencing ERP projects makes it easier to initiate a controlling of the project progress and a continuous monitoring of factors which are influencing the success in a negative or positive way. The project phases can help to isolate the CSFs which are important at the project phase the project of the company is in and to react in time.

In practice it is very difficult to identify the most critical success factors for ERP projects because they can vary from one project to the other and the importance of each CSF can differentiate too. But the aim should be to realise the importance and the effects of ERP-experiences and to use this to avoid active faults which could be avoided within ERP projects. The results are trends which are investigated through an extensive literature research and analyses. A problem which could influence the result is that researchers are may searching for well known CSF which were identified by a lot of publications in the past. It is possible that authors influence their findings in a special way, it e.g. authors raise CSF of a specific project which is basis of their research and they use a questionnaire with given answer possibilities it is clear that only the CSF mentioned can be found. Another possibility to identify CSF in ERP projects is a "lessons learned" report which is created by project members.

\section{Explanation of the Results}

The columns numbered from 1 to 23 show the publications in which the CSFs were found and which CSFs were mentioned in the according publication. The CSFs mentioned in each publication were aggregated to umbrella terms. The sum at the bottom of the table shows how many CSFs were identified by the author of the publication. The sum at the right shows the number of occurrence of the according CSF in the reviewed literature. This sum shows the importance of CSF because it reports how many of the considered authors identified the according CSF.

Column A displays the ranking of the CSF considering the number of occurrence in publications in percent. B shows the absolute ranking of the CSF and column $\mathrm{C}$ shows the number of occurrences in the 3 defined project phases.

Column D shows the classification of the CSFs according to the possibility to quantify and measure the CSF. Measurable CSFs are easier to control. It is possible to build project plans where the progress of these CSFs can be monitored. Hard means that the possibility to quantify the CSF is higher than for soft CSFs. The separation of CSFs into 2 groups is needed for the analysis in the section where the CSF trends are indicated because nowadays every project needs different possibilities for quantification of results, resources, time, budget, skills of project team members and different other controlled quantities.

Column A of Table 3 shows that top management support is the most important CSF according to the number of occurrence $(12,00 \%)$ and is critical in 3 project phases. In combination of the 2 rankings it seems to be the most important critical success factor in ERP projects. Team composition \& teamwork has an occurrence of $10,29 \%$ and is critical in 3 project phases too. Project management has an absolute occurrence of $10,86 \%$ but it seems to be a critical success factor in only one project phase. It is possible that a cumulative consideration would rank team composition \& teamwork higher than project management because team composition and teamwork has critical impact over all project phases.

Table 3 additionally shows that some CSFs seem to have only little influence on the ERP project success. Vendor support has the lowest ranking according to the number of occurrence $(0,57 \%)$. Maybe this is a result of the possibility to buy external knowledge from consulting firms especially if the company has a prevalent ERP system. These externals are supporting ERP projects and vendor support as a CSF is not as important.

\section{CSF TRENDS FROM DIFFERENT ASPECTS}

In this section the CSFs which were identified and shown in Table $\mathbf{3}$ are classified from different points of view. First of all the publications of Table $\mathbf{3}$ were classified according to their publication year. In a second step the percentage of the authors who identified the according CSF in the according year was calculated and analysed. Afterwards the country the author(s) is / are coming from were identified and used to classify the publications according to the continent. To group the CSF into continents is used to show the cultural impact on CSFs in ERP projects. The publication [56] was assigned to Europe because the university from the author of the publication is in the European part of Turkey.

That means that dependent variables (year of publication / continent) were defined which are influencing the CSFs (independent variables) in the publications. The findings are shown in Figs. (2 and 3). The findings should help further researches to understand which factors are possible dependent variables influencing the importance of CSFs in the ERP project. The definition of dependent variables provides innumerable possible different constellations, the classification into time periods and origin of the authors are only partial aspects of the possible constellations.

\section{Publication Year}

Fig. (2) shows the trend of CSF research between 1998 and 2006. The publications from Table $\mathbf{3}$ were categorised according to their publishing date into 3 groups. Group 1 consists of the CSF publications between 1998 and 2001, group 2 of the publications between 2001 and 2003 and group 3 of the publications between 2004 and 2006. The trend shows that some CSFs like project champion / empowered decision makers, software development, testing, troubleshooting and deliverable dates / smaller scope were not mentioned in the latest publications in this field. This could be a result of the improvement of ERP solutions or of lessons learned in ERP projects. Some CSFs like top management support were identified constantly over the years. The values of Fig. (2) show the percentage of the authors which identified the CSF in the according year. It shows the importance of CSFs in the literature over the years. The CSF user 


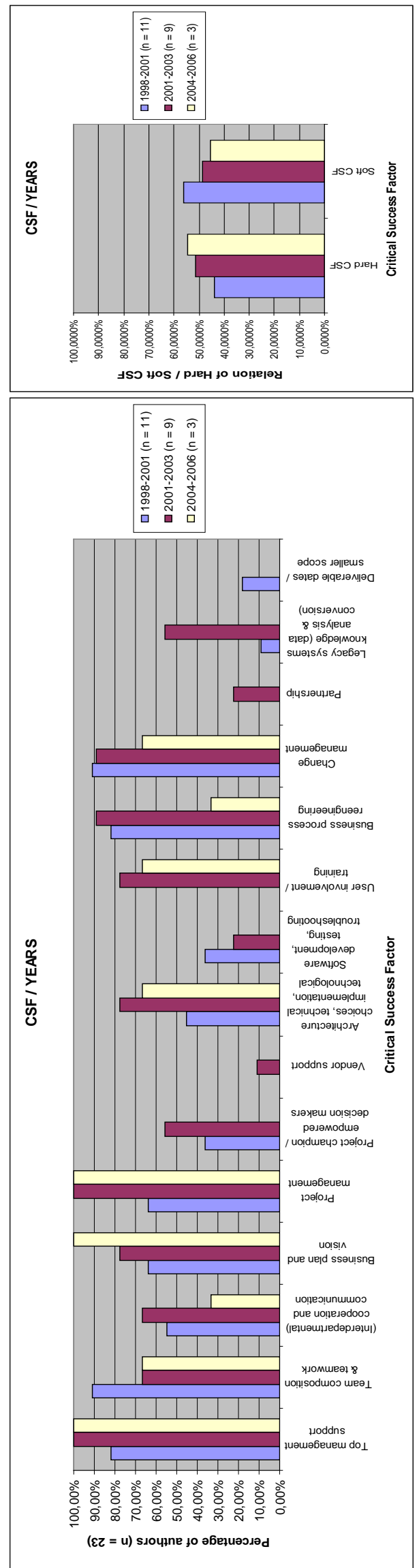

Fig. (2). CSF / year.

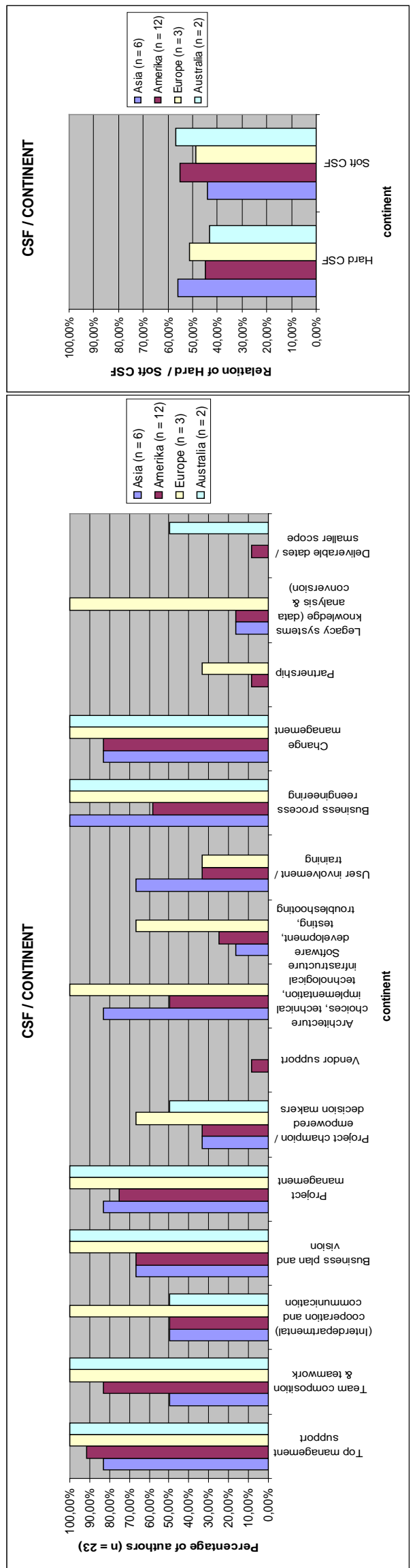

Fig. (3). CSF / continent. 
involvement / training was not mentioned between 1998 and 2001 and has a high percentage in the years $2001-2006$. The trend of this CSF could be a result of unsatisfying results which were made when the users were not integrated into ERP-projects in the past. Business plan and vision shows an upward curve between 1998 and 2006. The importance of a clear business plan and a vision what should be the result of the project is very important to evaluate the success afterwards. The importance of this CSF increased steadily and it seems that companies recognised the importance. Some CSFs like vendor support, partnership and deliverable dates / smaller scope seem to be of less importance in ERP projects. But the most interesting finding is that the relation of hard and soft critical success factors is changing over time. In the first time period the relation of identified hard CSFs to soft is $44,00 \%$ to $56,00 \%$. In the second period it is $51,55 \%$ to $48,45 \%$ and in the last period it is $54,60 \%$ to $45,40 \%$. It shows that the identification of measurable success factors was increasing over the last years. The importance of easier to measure success factors seems to be increasing over time and the influence of soft CSFs seems to decrease. A possible explanation is that this is a result of nowadays project work which is always trying to make everything measurable and controllable even IT projects. Quantification implicates measurable success, measurable results and measurable progress which are more transparent than soft CSF. tions:

The clusters of Fig. (2) contain the following publica-

\begin{tabular}{|l|l|}
\hline $1998-2000$ & {$[11,14,22,23,28,33,53,54,58,59,61]$} \\
\hline $2001-2003$ & {$[20,25,29-31,56,60,62,63]$} \\
\hline $2004-2006$ & {$[2,4,13]$} \\
\hline
\end{tabular}

\section{Continent of Origin}

Fig. (3) shows the CSFs of Table $\mathbf{3}$ considering the continent the author is coming from. The values show the percentage of the authors who identified the according CSFs. Fig. (3) shows that the CSFs are not equal in every continent in which the research was made. It seems that the occurrence of CSFs is depending on the cultural environment the author is coming from. The continent is the independent variable which is influencing the depending variables (the CSFs). The CSFs top management support, project management and change management seem to be of critical impact on every continent the CSFs were identified. The percentage of the authors who identified the according CSF is always over 75 $\%$. (Interdepartmental-) cooperation and communication and legacy systems knowledge (data analysis \& conversion) was identified by $100 \%$ of the European publications. It seems that this CSFs are most critical in European ERP projects. Especially legacy systems knowledge (data analysis \& conversion) has a ranking of $100 \%$ in Europe, only 16,67 \% in Asia, $0 \%$ in Australia and $16,67 \%$ in America. The classification into hard and soft CSFs shows that the relation of Australia, which is $43,36 \%$ to $56,64 \%$ and the USA which has a relation of $44,87 \%$ to $55,13 \%$ is very similar. In Europe hard CSF are a little bit more important and in Asia hard CSF show a percentage of 55,83\%.
The clusters of Fig. (3) contain the following publications:

\begin{tabular}{|l|l|}
\hline Asia & {$[2,14,25,30,60,61]$} \\
\hline America & {$[4,11,13,23,28,29,31,33,58,59,62,63]$} \\
\hline Europe & {$[20,22,56]$} \\
\hline Australia & {$[53,54]$} \\
\hline
\end{tabular}

\section{CONCLUSION}

Enterprise resource planning systems represent standardised software packages which are not custom developed according to the specific needs of organisations. Some vendors offer adequate branch ERP packages which should fit to the processes and the needs of organisations in a better way than traditional ERP packages. But not only processes are different, branches also need specific interfaces to the subsystems which are used to endorse the needs of the business in general.

Business needs are changing rapidly, new requirements are often influencing branches and Vanilla ERP is not possible when new business needs come up and the company wants to hold up or achieve competitive advantage. That's why many ERP projects are risky, costly and long lasting business ventures which are not running smoothly in a usual way.

The ranking developed in this paper identifies 15 CSFs which should help further investigations and ERP implementers to identify possible problems and to detect the possible negative influence on the project success in an early phase and to steer a successful course during the ERP implementation. The project phases show when specific CSFs are important for the success of the ERP project and when they should be considered. Companies starting ERP projects should learn to identify critical factors which are affecting the project success and ensure that the potential risks are avoided when the project management and the team members are controlling the project progress and the potential occurrence of CSF.

The development of the CSF-model was motivated by ERP projects trying to improve the performance of ERP systems. The CSF-ranking itself was developed from the literature, and extends existing rankings. It shows which factors are significant for a certain period of time and when those factors have to be considered by ERP project teams. The limitation is the low number of publications. Furthermore the different analyses which were made indicate trends which are recognisable. These trends could be investigated in surveys in the future. It is very difficult to build a ranking of CSF because of the different things which are influencing the importance of CSFs in different projects because every project has it's own staffing and it's own complexity and differs from other projects.

A validation of the results would be a new investigation possibility in the field of CSF in ERP projects. Within the scope of this study on CSFs some interesting new research questions for future research were found. According to different needs of different branches it implicates that the CSFs are diverging too. Another possible research question is the 
deviation of CSFs during ERP implementation projects depending on the ERP-vendor (and the package implementing) or how CSFs are ranked by ERP experts in the defined project phases. Another interesting research question is how the experience of ERP-experts influences their personal ranking of CSFs. Further research in the field of CSFs is needed to investigate the mentioned influences of CSFs in ERP projects.

\section{REFERENCES}

[1] N. Gronau, Industrielle Standardsoftware: Auswahl und Einführung. Munich: Oldenbourg, 2001, pp. 282-289.

[2] T.R. Bhatti, "Critical success factors for the implementation of enterprise resource planning (ERP): empirical validation," in The Second International Conference on Innovation in Information Technology (IIT'05), 2005, pp. 1-10.

[3] M. May, Business Process Management-Integration in a webenabled environment. Pearson Education, Great Britain, 2003.

[4] F. F.-H. Nah, S. Delgado, "Critical Success factors for Enterprise resource Planning Implementation and upgrade," Journal of Computer Information Systems, pp. 99-113, 2006.

[5] T. H. Davenport, "Putting the enterprise into the enterprise system," Harvard Business Review, (July-August), pp. 121-131, 1998.

[6] W. R. King, "Ensuring ERP Implementation success," Information Systems Management. Vol. 22, No. 3, pp. 83-84, 2005.

[7] D. Cooke, L. Gelman, W. J. Peterson, ERP Trends. New York: The Conference Board, 2001, pp. 1-28.

[8] F. F.-H. Nah, K. M. Zuckweiler, J. L.-S. Lau, "ERP implementation: chief information officers 'Perceptions of Critical Success Factors," International Journal of Human-Computer Interaction, Vol.16, No. 1, pp. 5-22, 2003.

[9] S. A. Sherer, S. Alter, "Information System Risk and Risk Factors: Are they mostly about information systems?," in Communications of the Association of Information Systems, Vol. 14, pp. 29-64, 2004.

[10] J. Esteves, J. Pastor, J. Casanovas, "Measuring Sustained Management Support in ERP Implementation Projects: A GQM Approach," in Americas Conference on Information Systems, Dallas Texas, USA, 2002.

[11] P. Bingi, M. Sharma, J. Godla, "Critical issues affecting an erp implementation," Information Systems Management, Vol. 16, Issue 3, pp. 7-15, 1999.

[12] M. Sumner, "Critical success factors in enterprise wide information systems projects," in Proceedings of the American Conference on Information Systems, 1999, pp. 232-234.

[13] A. I. Nicolaou, "ERP Systems Implementation: Drivers of PostImplementation Success," DSS2004 Conference Proceedings, 2004 pp. 589-597.

[14] Y. F. Jarrar, A. Al-Mudimigh, M. Zairi, "ERP Implementation critical success factors-the role and impact of business process management," in ICMIT Proceedings of the 2000 IEEE International Conference on Information Technology, 2000, pp. 122-127.

[15] P. S. Frantz, A. R. Southerland, J. T. Johnson, (Number 4, 2002). ERP Software Implementation Best Practices. Educause Quarterly, pp. 38-45 [On-line], Available: http://net.educause.edu/ir/library/ pdf/EQM0246.pdf [January 2009].

[16] J. Magnusson, A. Nilsson, F. Carlsson, "Forecasting ERP Implementation Success-Towards a grounded framework," in European Conference on Information Systems, Turku, Finland, 2004.

[17] F. F.-H. Nah, J. L.-S. Lau, "Critical factors for successful implementation of enterprise systems." Business Process Management Journal, Vol. 7, Issue 3, pp. 285-296, 2001.

[18] M. Al-Mashari, S. K. Ghani and W. Al-Rashid, "A study of the Critical Success Factors of ERP implementation in developing countries," International Journal of Internet and Enterprise Management, Vol. 4, No. 1, pp. 68-95, 2006.

[19] J. Esteves-Sousa, J. Pastor-Collado, "Towards the unification of critical success factors for ERP-implementations," in $10^{\text {th }}$ Annual Business Information Technology Conference (BIT), Manchester, 2000.

[20] J. Esteves, J. Pastor, "Analysis of critical success factors relevance along sap implementation phases," in Seventh Americas Conference on Information Systems, Boston, Massachusetts, USA, 2001.
[21] J. Ranzhe, Q. Xun, "A Study on Critical Success Factors in ERPSystems Implementation," in International Conference on Information Systems, Montréal Québec, Canada, 2007.

[22] C. P. Holland, B. Light, "A critical success factors model for ERP implementation." IEEE Software, Vol. 16 Issue 3, pp. 30-35, 1999.

[23] S. Buckhout, E. Frey, J. Nemec, "Making ERP Succeed: Turning Fear into Promise," IEEE Engineering Management Review, Vol. 19, pp.116-123, 1999.

[24] S. Ghosh, "Challenges on a global implementation of ERP software," in Engineering Management Conference (IEMC '02), 2002, pp. 101-106.

[25] L. L. Zhang, K. O. Matthew, Z. Zhang, P. Banerjee, "Critical Success Factors of Enterprise Resource Planning Systems Implementation Success in China," in Proceedings of the $36^{\text {th }}$ Hawaii International Conference on System Sciences, Hawaii, 2003.

[26] G. B. Alleman, "Agile Project Management Methods for ERP: How to Apply Agile Processes to Complex COTS Projects and Live to Tell About It," in Extreme Programming and Agile Methods: XP/Agile Universe, Springer Verlag, 2002, pp. 70-88.

[27] L. Roure, "Cultural Differences in Product Champions Characteristics: A comparison of France and Germany," DMSP-C - 99-268, INIST-CNRS, Mars, Ardéche, France,1999.

[28] M. Sumner, "Risk factors in enterprise-wide/ERP projects," Journal of Information Technology, Vol. 15, pp. 317-327, 2000.

[29] T. M. Somers, K. Nelson, "The Impact of Critical Success Factors across the Stages of Enterprise Resource Planning Implementations," in Proceedings of the $34^{\text {th }}$ Hawaii International Conference on System Sciences, Hawaii, 2001.

[30] M. Al-Mashari, A. Al-Mudimigh and M. Zairi, "Enterprise resource planning: A taxonomy of critical factors," European Journal of Operational Research, Vol. 146, Issue 2, pp. 352-364, 2003.

[31] E. J. Umble, R. R. Haft, M. M. Umble, "Enterprise resource planning: Implementation procedures and critical success factors," European Journal of Operational Research, vol. 146, pp. 241-257, 2003.

[32] D. Patel, J. Picard, "Systems bypass, process breakdown," Industrial Engineer, Vol. 39, Issue 5, pp. 30-34, 2007.

[33] S. Wee, "Juggling Toward ERP Success: Keep Key Success Factors High," ERP News (February 2000), pp. 1-5.

[34] S. Haag, P. Baltzan, A. Phillips, Business Driven Technology, $2^{\text {nd }}$ ed. Irwin, Mc Graw Hill, 2005.

[35] J. Esteves, J. Pastor, J. Casanovas, "Monitoring business process redesign in erp implementation projects," in Americas Conference on Information Systems 2002, Proceedings Paper 125, 2002.

[36] E. Van Stijn, A. Wensley, "ERP's best practices and change: an organizational memory mismatch approach," in European Conference on Information Systems, Regensburg, Germany, 2005.

[37] V. Bosilj-Vuksic, M. Spremic, "ERP system implementation and business process change: case study of a pharmaceutical company," Journal of Computing and Information Technology, Vol. 13, pp. 11-24, 2005.

[38] E. Fosser, O. H. Leister, C. E. Moe, "Organisations and vanilla software: What do we know about ERP systems and competitive advantage?" in European Conference on Information Systems, Galway, Irland, 2008.

[39] M. L. Markus, S. Axline, D. Petrie, C. Tanis, "Leraning from adopters' experiences with ERP: problems encountered and success achieved," Journal of information technology, pp. 245-265, 2000.

[40] A. N. Parr, G. Shanks, "A Taxonomy of ERP Implementation Approaches," in Proceedings of the $33^{\text {rd }}$ Hawaii International Conference on System Sciences, Hawaii, 2000 pp. 1-10.

[41] R. B. Kvavik, R. N. Katz, The Promise and Performance of Enterprise Systems. ECAR Research Study, 2002, [On-Line] Available: http://net.educause.edu/ir/library/pdf/ERS0204/rs/ers0204w.pdf [January 2009].

[42] J. W. Noyes, (Number 2, 2003). The ERP Dilemma: "Plain Vanilla" Versus Customer Satisfaction-Customization of an ERP implementation can interfere with schedules and budgets, yet it makes users happier. [On-line], Educause Quarterly, Available: http:// net.educause.edu/ir/library/pdf/EQM0327.pdf [January 2009].

[43] B. Dehning, V. J. Richardson, "Returns on Investments in Information Technology: A Research Synthesis," Journal of Information Systems, Vol. 16, No. 1, pp. 7-30, 2002.

[44] S. Parthasarathy, N. Anbazhagan, M. Ramachandran, "An exploratory case study on performance enhancement oF ERP Projects," INFOCOMP Journal of Computer Science, pp. 1-8, 2006. 
[45] T. Hoffman. "Global ERP," Computerworld, pp. 36-38, 2007.

[46] E. Lawson, C. Price, "The psychology of change management," The McKinsey Quarterly, (Number 2 Organisation), 2003.

[47] A. M. Aladwani, "Change management strategies for successful ERP implementation," Business Process Management Journal, Vol. 7, No. 3, pp. 266-275, 2001.

[48] J. W. Ross, "Surprising Facts About Implementing ERP." IEEE IT Pro (July / August, 1999), pp. 65-68.

[49] I. Kemppainen, "Change Management perspectives in an ERPImplementation," in European Conference on Information Systems, 2004.

[50] M. N. Haines, D. L. Goodhue, "Implementation Partner Involvement and Knowledge Transfer in the Context of ERP Implementations," International Journal of Human-Computer Interaction, pp. 23-38, 2003.

[51] L. P. Willcocks, R. Sykes, "The Role of the CIO and it function in ERP," in Communications of the ACM, Vol. 43, No. 4, 2000, pp. 32-38.

[52] Y. Yusuf, A. Gunasekaran, M. S. Abthorpe, "Enterprise information systems project implementation: A case study of ERP in RollsRoyce," International Journal of Production Economics, vol. 87, pp. 251-266, 2004.

[53] A. Parr, G. Shanks, "A model of ERP project implementation," Journal of Information Technology, Vol. 15, pp. 289-303, 2000.

[54] G. Shanks, A. Parr, B. Hu, B. J. Corbitt, T. Thanasankit, P. Seddon, "Differences in Critical Success Factors in ERP Systems Implementation in Australia and China: A Cultural Analysis," in European Conference on Information Systems, Melbourne, Australia, 2000 .
[55] M. L. Markus, C. Tanis, The Enterprise System Experience-From Adoption to Success. Framing the Domains of IT Research: Glimpsing the Future Through the Past. R.W. Zmud, Ed. (Pinnaflex Educational Resources, Inc.: Cincinnati, Chapter 10, 2000, pp. 173 207.

[56] O. Kerimoğlu, E. Uluhan, 2003, "Critical Success Factors Affecting the Success of an ERP System Implementation," Unpublished project manuscript, Available: http://www.mis.boun.edu.tr/erdem/ mis517/projects-03/eray-onur.doc [October 2008].

[57] G. Falkowski, P. Pedigo, B. Smith, D. Swanson, "A Recipe for ERP Success," Beyond Computing, pp. 44-45, 1998,

[58] C. Francalanci, "Predicting the implementation effort of ERP projects: empirical evidence on SAP/R3," Journal of Information Technology, pp. 33-48, 2001.

[59] C. V. Brown, I. Vessey, "ERP Implementation Approaches: Toward a Contingency Framework," in Proceedings of the $20^{\text {th }}$ Inter national Conference on Information Systems, 1999, pp. 411-416.

[60] A. Al-Mudimigh, M. Zairi and M. Al-Mashari, "ERP Implementation: An Integrative Methodology," I3E Zürich, 549-560, 2001.

[61] J.G. Rosario, "On the Leading Edge: Critical Success Factors in ERP Implementation Projects," Philipines, Business World, 2000.

[62] M. Murray, G. Coffin, "A Case Study Analysis of Factors for Success in ERP System Implementations," in Proceedings of the Seventh American Conference on Information Systems, 2001 pp. 10121018 .

[63] A. Khan, Implementing SAP with an ASAP Methodology Focus. USA: iUniverse Inc., 2002 pp. 62-64.

(C) Kronbichler et al.; Licensee Bentham Open.

This is an open access article licensed under the terms of the Creative Commons Attribution Non-Commercial License (http://creativecommons.org/licenses/by-nc/3.0/) which permits unrestricted, non-commercial use, distribution and reproduction in any medium, provided the work is properly cited. 